Ridho, et al/Jurnal Ekonomi Syariah Teori dan Terapan Vol. 6 No. 6 Juni 2019: 1228-1241; DAMPAK PEMBAYARAN ZAKAT TERHADAP PERILAKU KONSUMSI PEGAWAI NEGERI SIPIL DI DEPARTEMEN AGAMA KOTA SURABAYA

\title{
DAMPAK PEMBAYARAN ZAKAT TERHADAP PERILAKU KONSUMSI PEGAWAI NEGERI SIPIL DI DEPARTEMEN AGAMA KOTA SURABAYA ${ }^{1}$
}

\author{
Aris Kurniawan Ridho \\ Departemen Ekonomi Syariah - Fakultas Ekonomi dan Bisnis - Universitas Airlangga \\ Email: aris.kurniawanridho@gmail.com
}

Sri Herianingrum

Departemen Ekonomi Syariah - Fakultas Ekonomi dan Bisnis - Universitas Airlangga

Email: sriheria@gmail.com

\begin{abstract}
:
The objective of this study is to find out how the impact of Paying Zakat on consumptive behavior of civil servants in the Department of Religion of Surabaya. The research used qualitative descriptive case study method. The data used were primary and secondary data. The primary data was obtained from the results of interview, observation, and documentation on the relevant parties, while secondary data was obtained through printed media, electronic media as well the Internet on consumptive behavior, in addition to supporting data from various journals and books which are relevant to this study. The results of the research show that zakat gives impact on consumptive behavior of Civil Servants of the Department of Religion in Surabaya. When their salary is deducted in accordance with the provisions of zakat, they feel that the consumptive behavior to fulfill their daily needs is somewhat different when they pay zakat. The efficiency of zakat payment or zakat collection is one of their reasons to continue paying their zakat in accordance with existing provisions. Among the greatest benefits they perceived is the increasing awareness of the obligation to pay zakat and applying consumption principles in accordance to the Islamic norms.
\end{abstract}

Keywords: zakat, consumptive behavior in Islam

\section{PENDAHULUAN}

\section{Latar Belakang}

Zakat merupakan kewajiban bagi seluruh umat Islam yang memenuhi kriteria. Dalam hadits yang diriwayatkan oleh Ibnu Abbas bahwa Rasulullah berkata: "Sesungguhnya Allah telah mewajibkan mereka zakat dari harta mereka yang diambil dari orang-orang kaya di antara mereka dan dibagikan kepada orangorang fakir di antara mereka." Zakat juga merupakan pembersih harta yang membuat harta orang yang berzakat lebih berkah.

Zakat merupakan salah satu pilar agama Islam yang selain selain berdimensi ibadah juga dinilai sangat efektif dalam mengurangi masalah sosial (Kalimasada,2013;210). Seperti kemiskinan, kriminalitas, dan pemerataan kesejahteraan ekonomi.

Orang yang membayar zakat disebut sebagai Muzakki dan orang yang menerima zakat disebut Mustahiq. Di era yang modern seperti saat ini, pembayaran zakat sangat mudah karena terdapat

\footnotetext{
1 Jurnal ini merupakan bagian dari skripsi Aris Kurniawan, NIM: 041311433118 , yang diuji pada tanggal 21 Maret 2019.
} 
Ridho, et al/Jurnal Ekonomi Syariah Teori dan Terapan Vol. 6 No. 6 Juni 2019: 1228-1241; DAMPAK PEMBAYARAN ZAKAT TERHADAP PERILAKU KONSUMSI PEGAWAI NEGERI SIPIL DI DEPARTEMEN AGAMA KOTA SURABAYA

berbagai fasilitas yang bisa digunakan. Yang sering kita temukan adalah Lembaga Amil Zakat atau Badan Amil Zakat di sekitar lingkungan kita. Bahkan pembayaran zakat pun bisa melalui online dan tidak perlu datang ke Lembaga atau Badan Zakat.

Zakat di Indonesia sudah berjalan lama dan sudah diatur dalam Undang Undang Nomor 23 Tahun 2011 tentang pengelolaan zakat. Kesadaran akan pembayaran zakat sudah meningkat dari tahun ke tahun. Dana zakat juga bisa bermanfaat untuk kepentingan pembangunan sebuah nergara karena zakat bisa digunakan untuk pembangunan infrastruktur dan kepentingan Negara lainnya.

Berdasarkan penelitian yang dilakukan oleh Badan Amil Zakat Nasional (BAZNAZ) potensi zakat nasional pada tahun 2015 sebesar Rp 286 Triliun atau sebesar 2,4\% GDP. Dari data tersebut dapat dilihat bahwa penyerapan dana zakat tidak bisa di pandang sebelah mata. Penyerapan dana zakat bisa digunakan pemerintah untuk berbagai kepentingan Negara.

Banyak masyarakat yang belum tahu bahwa zakat mempunyai manfaat yang banyak salah satunya yaitu Zakat sebagai pengurang Penghasilan Kena Pajak (PKP). Dalam ketentuan perpajakan yang berlaku di negara kita, khususnya yang terkait dengan PPh adalah Undang-
Undang Nomor 7 Tahun 1983 tentang Pajak Penghasilan sebagaimana telah beberapa kali diubah terakhir dengan UndangUndang Nomor 36 Tahun 2008 dan diatur lebih lanjut dengan Peraturan Pemerintah Nomor 60 Tahun 2010 bahwa zakat atau sumbangan keagamaan yang sifatnya wajib dikurangkan dari penghasilan bruto. Kebijakan Ditjen Pajak juga menetapkan bahwa terhadap Wajib Pajak orang pribadi yang ketika penyampaian SPT Tahunan PPh yang menyatakan kelebihan bayar (termasuk lebih bayar karena pemotongan zakat), niscaya akan dilakukan pengembalian kelebihan pembayaran pajaknya tanpa melalui pemeriksaan, tetapi cukup dengan penelitian oleh pegawai pajak.

Kementerian Agama merupakan lembaga pemerintahan yang di dalamnya banyak memiliki peran terhadap sosialisasi yang berhubungan dengan keagamaan. Salah satu hal yang dapat dilakukan oleh kementrian agama adalah menyosialisasikan tentang zakat dengan memotong penghasilan kena pajak pegawai untuk pembayaran zakat.

Kementrian Agama kota Surabaya telah melakukan kebijakan pembayaran zakat kepada aparatur sipil negara melalui pemotongan gaji. Setiap bulan gaji yang diterima oleh aparatur sipil negara kota Surabaya secara otomatis terpotong sebesar 2,5 \% untuk pembayaran zakat. 
Ridho, et al/Jurnal Ekonomi Syariah Teori dan Terapan Vol. 6 No. 6 Juni 2019: 1228-1241; DAMPAK PEMBAYARAN ZAKAT TERHADAP PERILAKU KONSUMSI PEGAWAI NEGERI SIPIL DI DEPARTEMEN AGAMA KOTA SURABAYA

Pengelolaan tersebut secara langsung dilakukan oleh Unit Pengumpul Zakat kementrian Agama yang dibawah langsung dari Badan Amil Zakat Nasional (Baznas).

Konsep konsumsi merupakan pembelanjaan yang dilakukan oleh rumah tangga atas barang dan jasa dengan tujuan untuk memenuhi kebutuhan dari pelaku konsumsi tersebut. pembelanjaan atas kebutuhan primer, sekunder, maupun tersier digolongkan pada pengeluaran konsumsi (Sukirno, 2000). Kegiatan konsumsi sendiri menjadi sebuah kebutuhan yang harus dilakukan oleh setiap individu rumah tangga.

Besaran konsumsi individu sangat dipengaruhi oleh pendapatan yang didapatkan oleh individu itu sendiri. semakin besar pendapatan seseorang maka konsumsi orang tersebut cenderung naik. Setelah adanya kebijakan zakat yang dipotong dari gaji maka hal tersebut akan memberikan dampak bagi jumlah pendapatan yang diterima, sehingga secara matematis akan memberikan dampak juga pada perilaku konsumsi seseorang tersebut.

\section{LANDASAN TEORI ZAKAT}

Zakat menurut bahasa memiliki banyak arti (Ad Dimasyqi, 2005:251). Diantaranya adalah berkembang (an numuww), bertambah kebaikan (al barakah), dan banyak barakah (katsrat al khair). Kedatangan Islam di dunia pada abad ke tujuh telah menambahkan satu makna lagi bagi kata zakat. Secara istilah zakat merupakan kadar harta tertentu yang dialokasikan kepada kelompok tertentu dengan aturan-aturan khusus. Aturan khusus tersebut ditentukan oleh syari'at Islam, seperti satu sha' beras $(2,7 \mathrm{~kg})$ untuk zakat fitrah, satu ekor kambing untuk 5 ekor unta, 2,5\% dari emas yang sudah mencapai satu mitsqal $(77,58$ gram untuk emas 24 karat).

Perintah tentang zakat tertulis di dalam firman Allah surat At Taubah ayat 103, yang artinya, "Ambillah zakat dari sebagian harta mereka, dengan zakat itu kamu membersihkan dan mensucikan mereka dan mendoalah untuk mereka. Sesungguhnya doa kamu itu (menjadi) ketenteraman jiwa bagi mereka. dan Allah Maha mendengar lagi Maha mengetahui".

Ada beberapa harta yang wajib dizakati sesuai (Sudirman, 69; 2007). Pertama zakat mal yaitu zakat yang dikeluarkan atas harta yang dimiliki atau dikuasai oleh seseorang. Beberapa arti tentang mal mencakup sesuatu yang dimiliki, kuasai maupun disimpan, serta harta yang dapat diambil manfaatnya.

\section{Rukun dan Syarat Zakat}

Rukun zakat menurut Az Zuhaili (1985:737) yaitu orang yang mengeluarkan zakat dan orang yang menerima zakat. Adapun orang yang menerima zakat dapat 
Ridho, et al/Jurnal Ekonomi Syariah Teori dan Terapan Vol. 6 No. 6 Juni 2019: 1228-1241; DAMPAK PEMBAYARAN ZAKAT TERHADAP PERILAKU KONSUMSI PEGAWAI NEGERI SIPIL DI DEPARTEMEN AGAMA KOTA SURABAYA

langsung ataupun wakil atau pengganti seperti Imam dan lembaga yang menerima dan menyalurkan zakat.

Syarat harta yang wajib dizakati adalah (Yasin, 2012:17) adalah:

1. Mencapai Nisab

Nisab adalah syarat minimal dari harta yang wajib dizakati. Setiap harta yang dikategorikan sebagai harta wajib zakat memiliki nisab yag berbeda-beda. Jika harta zakat telah mencapai satu nisab maka seseorang wajib mengelvarkan zakat. Besaran zakat yang wajib dikeluarkan berbeda-beda, tergantung pada jenis kategori harta zakat.

2. Kepemilikan Sempurna

Yasin (2012:16) menjelaskan bahwa kepemilikan sempurna adalah pemilik harta dapat mempergunakan atau mengambil manfaat dari harta tersebut secara sempurna. Harta-harta tersebut dapat berupa hasil dari perdagangan yang halal, pemberian negara, harta warisan, dan harta-harta lainnya yang telah memenuhi syarat. Adapun harta-harta yang didapatkan dari perbuatan haram (mencuri, merampok, dll) tidaklah wajib dizakati karena sejatinya harta tersebut tidak dimiliki secara sah oleh pemilik.

3. Haul (Kepemilikan selama satu tahun)

Haul atau harta dimiliki selama setahun, dalam hal ini jumlah hari dalam hitungan tahun qomariyyah. Yasin (2012:17) menjelaskan bahwa persyaratan satu tahun berlaku bagi harta ternak, harta benda yang diperdagangkan, dan yang lainnya. Adapun hasil pertanian tidak disyaratkan untuk menunggu satu tahun.

4. Melebihi kebutuhan pokok

Yasin (2012:18) menjelaskan bahwa kebutuhan pokok adalah kebutuhan minimal yang diperlukan sehari-hari untuk menjaga kelestarian hidup seseorang. Hal tersebut dapat diartikan bahwa apabila kebutuhan tersebut tidak terpenuhi maka seseorang tersebut tidak dapat hidup dengan layak. Kebutuhan pokok tersebut merupakan kebutuhan primer yang terdiri dari pangan, sandang, papan, dan kesehatan.

5. Harta zakat dapat di produktifkan atau bernilai produktif

Az zuhaili (736;1985) menjelaskan bahwa menurut madzhab Hanafiyyah mengatakan bahwa tidak ada zakat pada harta yang tidak berkembang. Maksud dari harta yang dapat berkembang tersebut adalah harta tersebut mampu bertambah dengan misalnya digunakan untuk modal usaha seperti vang, hasil pertanian, dll.

\section{Zakat Profesi}

Al Qardlowi di dalam Aziz $(2014 ; 192)$ menjelaskan jika profesi dibagi menjadi dua hal. Pertama, Kasb al Amal yaitu pekerjaan seseorang yang tunduk pada perseroan dengan mendapatkan upah. Kedua, Mihan al Hurrah yaitu pekerjaan bebas. Tidak terikat pada orang lain. 
Ridho, et al/Jurnal Ekonomi Syariah Teori dan Terapan Vol. 6 No. 6 Juni 2019: 1228-1241; DAMPAK PEMBAYARAN ZAKAT TERHADAP PERILAKU KONSUMSI PEGAWAI NEGERI SIPIL DI DEPARTEMEN AGAMA KOTA SURABAYA

Aziz (2014; 193) juga menjelaskan Apabila ditinjau dari bentuknya, usaha profesi tersebut bisa berupa:

1. Usaha fisik, seperti pegawai dan artis.

2. Usaha pikiran, seperti konsultan dan dokter.

3. Usaha kedudukan, seperti komisi dan tunjangan yang diterima dari sebuah jabatan.

4. Usaha modal, seperti investasi atau bisnis lainnya.

Sedangkan apabila ditinjau dari hasil usaha/gaji yang diterima, profesi dapat pertama, hasil yang teratur dan pasti, baik setiap bulan, minggu atau hari seperti upah pekerja dan gaji pegawai. Kedua, hasil yang tidak tetap dan tidak dapat diperkirakan secara pasti, seperti pengacara, royalti pengarang, konsultan dan artis.

Yasin (2012:36) menjelaskan jika zakat profesi didasarkan atas qiyas atau analogi atas karakteristik zakat yang telah ada. Zakat profesi didapat kewajiban zakat profesi merupakan kewajiban bagi umat Islam yang merupakan hasil dari ijtihad ulama yang belum ditetapkan sebelumnya, melalui dalil al Quran ataupun al Sunnah.

Aturan tentang zakat di Indonesia diatur oleh Undang-Undang No. 23 Tahun 2011. poin-poin penting yang menjadi materi UU No 23 Tahun 2011 tersebut antara lain, tentang asas pengelolaan zakat, tujuan pengelolaan zakat dan lain lain. Tentang asas pengelolaan zakat disebutkan dalam pasal 2 UU No.23 menyatakan bahwa pengelolaan zakat di Indonesia berasaskan: Syariat Islam, Amanah, Kemanfaatan, Kepastian Hukum, Keadilan, Terintegrasi, dan Akuntabilitas.

Adapun tentang zakat profesi dijelaskan dalam kolom (h) pasal 4 ayat (2) tersebut disebutkan bahwa diantara bentuk zakat mal adalah pendapatan dan jasa, ini artinya memberikan peluang terhadap bentuk aktifitas-aktfitas dan jasa yang menghasilkan pendapatan materi. Pada tahap inilah kemudian dimaknai bahwa setiap profesi yang menghasilkan pendapatan materi harus dikeluarkan zakatnya, sehingga gaji pegawai juga dapat ditarik zakat didalamnya.

Al Faizin dan Herianingrum (2018) menjelaskan jika pemerintah dapat menunjuk beberapa petugas yang menangani pengumpulan dan distribusi

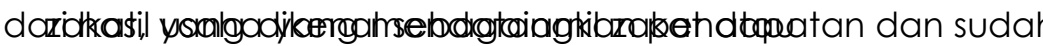
'āmilin. Ini adalah tugas Rasulullah yang representasi kepala negara saat itu kepada Mu'adz bin Jabal untuk diambil zakat di Zaman.

\section{Pengertian dan Tujuan Konsumsi}

Konsumsi merupakan kegiatan yang dilakukan oleh manusia untuk mencukupi kebutuhan hidupnya terhadap barang dan jasa. Konsumsi merupakan seluruh tipe aktifitas yang dilakukan sehingga dapat 
Ridho, et al/Jurnal Ekonomi Syariah Teori dan Terapan Vol. 6 No. 6 Juni 2019: 1228-1241; DAMPAK PEMBAYARAN ZAKAT TERHADAP PERILAKU KONSUMSI PEGAWAI NEGERI SIPIL DI DEPARTEMEN AGAMA KOTA SURABAYA

mencirikan tentang mereka, selain apa yang mereka lakukan untuk hidup (Chaney, 2003:54). Hakikat konsumsi adalah untuk memenuhi kebutuhan manusia, yang dimana kebutuhan tersebut dapat berupa kebutuhan primer, sekunder, maupun tersier.

Menurut Donslater (1997:113) dalam Pratiwi (2011:10) mengatakan bahwa konsumsi merupakan proses dimana manusia dan aktor sosial dengan segala sesuatu yang berhubungan dengan sesuatu yang dapat memuaskan mereka. Maka konsumsi konvensional juga mengacu pada seluruh aktifitas sosial yang dilakukan oleh setiap orang sehingga biasanya dipakai untuk mengenali diri mereka disamping apa yang mereka lakukan untuk hidup. Dari pengertian-pengertian secara konvensional diatas dapat diketahui jika konsumsi merupakan suatu aktivitas yang mereka lakukan untuk hidup serta mereka lakukan untuk mengenali diri mereka sendiri.

Tujuan konsumsi seseorang dalam Islam antara lain (Hakim:89-92) :

1. Untuk mengharap ridha dari Allah SWT.

2. Untuk mewujudkan kerjasama antar anggota masyarakat dan tersedianya jaminan sosial yang baik.

3. Agar dapat menumbuhkan rasa tanggung jawab individu terhadap kemakmuran diri, keluarga, serta masyarakat sebagai bagian aktivitas dan dinamisasi ekonomi.
4. Untuk meminimalisasi pemerasan dengan menggali sumber-sumber nafkah.

5. Supaya negara melakukan kewajibannya terhadap warga negara yang masih tergolong miskin.

\section{Konsumsi dalam Islam}

Asy Syatibi dalam Hidayat (2015:512) menjelaskan bahwa ada lima kebutuhan pokok yang esensial yang saling melengkapi dan tidak dapat dipisahkan. Kelima kebutuhan tersebut menjadikan manusia dapat bertahan dari eksistensinya, sehingga harus dijaga dan di pelihara. Kelima dasar tersebut adalah

1. Hifdzud ad-Din atau terpenuhinya kebutuhan akan agama yang diindikasikan oleh kokohnya keimanan dan ketakwaan.

2. Hifdzun an-Nafs atau terpenuhinya kebutuhan akan keamanan, kesehatan, keindahan, kehormatan diri,dan harga diri.

3. Hifdzul al-Aql atau terpenuhinya kebutuhan akan kecardasan yang diindikasikan oleh lamatahunnya pendidikan, produktivitas kemempuan meneliti, dan kemampuan mememukan hal-hal baru.

4. Hifdzun an-Nasl atau terpenuhinya akan ketentraman diri pribadi, kelvarga, hubungan kekeluargaan dan keturunan yang menjamin pergantian generasi.

5. Hifdzul al-Mal atau terpenuhinya 
Ridho, et al/Jurnal Ekonomi Syariah Teori dan Terapan Vol. 6 No. 6 Juni 2019: 1228-1241; DAMPAK PEMBAYARAN ZAKAT TERHADAP PERILAKU KONSUMSI PEGAWAI NEGERI SIPIL DI DEPARTEMEN AGAMA KOTA SURABAYA

kebutuhan akan air bersih, air suci dan menyucikan, udara yang segar, bahan bakar, listrik, sarana komunikasi dan informasi, sandang, pangan, kertas, dan papan.

Islam mengajarkan tentang cara berkonsumsi dengan benar sesuai ajaran AlQur'an maupun hadits sehingga mampu memberikan petunjuk yang jelas tentang konsumsi agar perilaku konsumsi menjadi terarah (Hidayat:2010). Manusia dalam melakukan pemenuhan kebutuhan hidupnya dan adakalanya perilaku konsumsi juga merupakan kebiasaan dan pemenuhan keinginan seseorang. Perilaku konsumsi yang sesuai dengan ajaran Islam akan memberikan jaminan kehidupan manusia yang adil dan sejahtera dunia dan akhirat.

Islam mendorong dan memberi
kebebasan kepada individu agar membelanjakan hartanya untuk membeli barang-barang yang baik dan halal dalam memenuhi kebutuhan hidup. Kebebasan itu pastinya diberikan dengan ketentuan tidak melanggar batas-batas yang suci serta mendatangkan bahaya terhadap keamanan dan kesejahteraan masyarakat dan negara. Terkait dengan hal tersebut Abu al-A'la al-Maududi memberikan penjelasan bahwa Islam menutup semua jalan bagi manusia untuk membelanjakan harta yang mengakibatkan kerusakan akhlak di tengah masyarakat, seperti judi yang hanya memperturutkan hawa nafsu.

Adapun nilai-nilai akhlak yang terdapat dalam konsep konsumsi adalah pelarangan terhadap sikap hidup mewah. Gaya hidup mewah adalah perusak individu dan masyarakat , karena menyibukkan manusia dengan hawa nafsu, melalaikannya dari hal- hal mulia dan akhlak yang luhur. Di samping itu, membunuh semangat jihad. Ali Abd arRasul juga menilai dalam maslah ini bahwa gaya hidup mewah (israf) merupakan faktor yang memicu terjadinya dekandansi moral masyarakat yang akhirnya membawa kehancuran masyarakat tersebut. Bagi Afzalur Rahman, kemewahan (israf) merupakan berlebih-lebihan dalam kepuasan pribadi atau membelanjakan harta untuk hal-hal yang tidak perlu.

Konsumsi setiap orang harus disesuaikan dengan kebutuhannya terhadap suatu barang atau jasa. Manusia dalam kegiatan konsumsi akan dihadapkan pada kebutuhan dan keinginan karena ingin membeli barang atau jasa muncul karena faktor kebutuhan dan keinginan (P3El,2008:130).

Mariana (2016:63) menjelaskan jika di dalam syariah, di dalam melaksanakan konsumsi seorang muslim harus mampu memaksimalkan nilai guna (utility). Nilai guna yang hendak ia dapatkan dari sebuah komoditas tidak boleh melampaui batas- batas yang telah ditetapkan di 
Ridho, et al/Jurnal Ekonomi Syariah Teori dan Terapan Vol. 6 No. 6 Juni 2019: 1228-1241; DAMPAK PEMBAYARAN ZAKAT TERHADAP PERILAKU KONSUMSI PEGAWAI NEGERI SIPIL DI DEPARTEMEN AGAMA KOTA SURABAYA

dalam syari'at Islam. Sistem ekonomi islam sendiri tidak secara mutlak menerima konsep utility dan preference dalam berkonsumsi, sehingga masih dapat menerimanya dalam batas wajar.

\section{Zakat dan Konsumsi Muzzakki}

Nafik (2013:24) menjelaskan jika fungsi konsumsi bagi pembayar zakat adalah $C_{1}=a_{1}+b_{1}(Y-Z-T)$

$A_{1}$ adalah konsumsi otonom dan $b_{1}$ adalah MPC dari para pembayar zakat. Nilai $b_{1}$ menunjukkan tentang kemiringan atau slope dari fungsi konsumsi tersebut. Maka, semakin besar pendapatan seseorang maka tingkat konsumsinya akan cenderung naik. Apabila tingkat konsumsi tersebut dipertahankan, maka akan meningkatkan ZIS (zakat, infak, dan shadaqah). Kenaikan ZIS akan memberikan dampak pada konsumsi mustahiq.

Adapun (Y-Z-T) merupakan pendapatan siap pakai para muzakki. Fungsi konsumsi muzakki dapat digambarkan melalui grafik berikut:

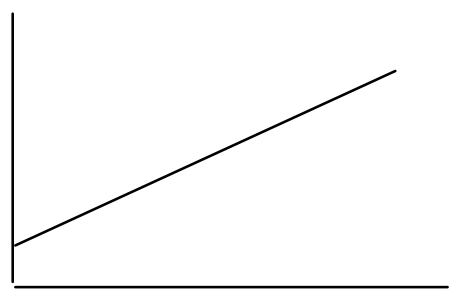

Gambar 1.

Fungsi Konsumsi Pembayar Zakat

III. METODE PENELITIAN

Pendekatan Penelitian
Penelitian ini membahas tentang bagaimana dampak yang terjadi pada pada perilaku konsumsi pegawai negeri sipil di Kementrian Agama Kota Surabaya setelah adanya kebijakan pembayaran zakat pada penghasilan bulanan. Penelitian ini menggunakan penelitian kualitatif yang menggunakan metode studi kasus deskriptif. Metode kualitatif merupakan penelitian yang memahami tentang fenomena yang dialami oleh objek penelitian seperti motivas, perilaku, tidakan, dan lainnya. Pemilihan metode kualitatif juga didasarkan pada rumusan masalah yang muncul. Rumusan masalah menggunakan pertanyaan "bagaimana" sehingga membutuhkan jawaban yang tidak dapat diperoleh dengan metode statistik.

Adapun studi kasus dipilih karena Menurut Yin (2014:9), studi kasus adalah strategi yang paling cocok bila pertanyaan suatu penelitian berhubungan dengan how ataupun why. Pendekatan studi kasus digunakan, karena merupakan penyelidikan empiris yang menyelidiki fenomena kontemporer dalam konteks kehidupan nyata. Pendekatan studi kasus juga lebih cocok digunakan karena tidak memilki peluang untuk melakukan kontrol terhadap obyek penelitian ( Yin, 2014:9).

Melihat pada objek yang akan diteliti, penelitian ini menggunakan studi kasus single case, dimana objek yang diteliti hanya pada satu kasus dan hanya pada 
Ridho, et al/Jurnal Ekonomi Syariah Teori dan Terapan Vol. 6 No. 6 Juni 2019: 1228-1241; DAMPAK PEMBAYARAN ZAKAT TERHADAP PERILAKU KONSUMSI PEGAWAI NEGERI SIPIL DI DEPARTEMEN AGAMA KOTA SURABAYA

satu objek penelitian. Penelitian ini ingin mengetahui tentang dampak yang terjadi pada perilaku konsumsi pegawai Kementrian Agama Kota Surabaya setelah diberlakukan kebijakan zakat yang menjadi pengurang pendapatan. Sehingga metode single case dinilai paling cocok untuk digunakan di dalam penelitian ini.

\section{Ruang Lingkup Penelitian}

Penelitian tentang perilaku konsumsi telah banyak dilakukan dengan objek penelitian yang berbeda-beda. Setiap masyarakat memiliki perilaku konsumsi yang berbeda antar satu sama lain. Penambahan atau pengurangan penghasilan seseorang akan memberikan dampak bagi perilaku konsumsi orang tersebut. Salah satu perkara yang menjadi pengurang penghasilan adalah diberlakukannya zakat penghasilan, yang dimana hal tersebut adalah suatu kebijakan yang diterapkan di Kementrian Agama Kota Surabaya. Kementrian Agama Kota Surabaya menerapkan pembayaran zakat rutin setiap bulan yang dipotongkan secara langsung dari gaji atau pendapatan bulanan pegawai.

Adapun ruang lingkup penelitian ini adalah mengacu pada rumusan masalah yang telah dipaparkan. Ruang lingkup penelitian ini terbatas pada bagaimana dampak dari kebijakan zakat sebagai pengurang penghasilan kena pajak pada perilaku konsumsi pegawai negeri sipil
Departemen Agama Kota Surabaya?

\section{Jenis dan Sumber Data}

Ada dua jenis data yang digunakan di dalam penelitian ini, yaitu data primer dan data sekunder. Data primer didapatkan dari informasi tentang bagaimana dampak dari kebijakan zakat sebagai pengurang penghasilan kena pajak pada perilaku konsumsi pegawai negeri sipil Departemen Agama Kota Surabaya. Adapun data sekunder yang digunakan sebagai penunjang adalah kepustakaan tentang zakat profesi maupun perilaku konsumsi dari sudut pandang Islam.

Menurut Yin (2008: 103) terdapat enam sumber bukti yang dapat dijadikan fokus bagi pengumpulan data, yaitu: dokumentasi, rekaman arsip, wawancara, observasi langsung, observasi partisipan, dan artefak. Sumber data primer yang digunakan adalah berasal dari wawancara mendalam dengan key informan, di mana key informan yang dijadikan sumber data dalam penelitian ini adalah pegawai Kementrian Agama Kota Surabaya yang merasakan dampak pada perilaku konsumsinya. Sedangkan untuk sumber data sekunder berasal dari buku, media massa, jurnal, maupun artikel yang berkaitan dengan topik penelitian, baik melalui media cetak maupun online.

\section{Teknik Pengumpulan Data}

Ada beberapa langkah yang dilakukan di dalam penelitian ini untuk 
Ridho, et al/Jurnal Ekonomi Syariah Teori dan Terapan Vol. 6 No. 6 Juni 2019: 1228-1241; DAMPAK PEMBAYARAN ZAKAT TERHADAP PERILAKU KONSUMSI PEGAWAI NEGERI SIPIL DI DEPARTEMEN AGAMA KOTA SURABAYA

mendapatkan data primer:

1. Persiapan Awal

Pada tahap ini, penulis mengurus surat izin penelitian skripsi secara formal kepada Fakultas Ekonomi dan Bisnis Universitas Airlangga sebagai kelengkapan administrasi dalam mengumpulkan data di Kementrian Agama Kota Surabaya serta data-data lain yang relevan.

2. Proses di lokasi atau obyek penelitian

Pada tahap ini penulis akan mendatangi kantor Kementrian Agama Kota Surabaya untuk menjelaskan maksud dan tujuan penulis dalam melakukan penelitian. Penulis melakukan proses wawancara dengan pejabat dan pegawai Kementrian Agama Kota Surabaya untuk mendapatkan data- data yang diperlukan terkait dengan penelitian.

\section{Pengumpulan Data}

Pada tahap ini, penulis mengumpulkan data dengan metode yang diperlukan, yaitu wawancara. Wawancara yang mendalam secara terbuka dengan pegawai Kementrian Agama dengan materi wawancara yang terus berkembang pada setiap pertanyaan, namun tetap fokus pada topik penelitian sehingga diperoleh data atau informasi yang semakin lengkap dan akurat, ditunjang dengan dokumen yang dimiliki oleh Kementrian Agama terkait dengan pendapatan atau gaji pegawai. Penulis juga menggunakan alat perekam sebagai alat pendukung selama wawancara berlangsung.

Pengumpulan data sekunder dilakukan dengan kajian studi pustaka yang membahas tentang zakat dan perilaku konsumsi menurut Islam. Pencarian studi pustaka terebut dapat dilakukan dengan tiga model. Pertama, mengumpulkan pustaka dari buku maupun jurnal-jurnal yang telah diterbitkan. Kedua, secara online, dengan menggunakan search engine peneliti dapat menemukan alamat website maupun referensi - referensi online terpercaya. Jurnal-jurnal tentang zakat dan perilaku konsumsi pun dapat diunduh melalui online. Ketiga, dimulai dengan mengetikkan alamat website pada URL yang ada di web browser. Hal ini hanya dapat dilakukan apabila penulis telah mengetahui alamat website yang akan ditujui.

\section{Teknik Keabsahan Data}

Pada penelitian kualitiatif keabsahan data dapat dilakukan ketika pada saat proses pengumpulan data. Di dalam teknik keabsahan data maka dilaksanakan pemeriksaan atas sejumlah data. Pada penelitian ini penulis menggunakan teknik triangulasi data.

Menurut Melong (2005: 330) triangulasi data adalah teknik pemeriksaan keabsahan data dengan memanfaatkan yang lain. Peneliti menyimpulkan bahwa dalam meneliti dibutuhkan keabsahan agar penelitian tersebut dapat dipercaya 
Ridho, et al/Jurnal Ekonomi Syariah Teori dan Terapan Vol. 6 No. 6 Juni 2019: 1228-1241; DAMPAK PEMBAYARAN ZAKAT TERHADAP PERILAKU KONSUMSI PEGAWAI NEGERI SIPIL DI DEPARTEMEN AGAMA KOTA SURABAYA

kredibilitasnya.

\section{Teknik Analisis Data}

Yin (2008:140) menjelaskan bentukbentuk teknik analisis data sebagai berikut:

1. Penjodohan Pola (pattern matching)

Teknik analisis penjodohan pola yaitu dengan menggunakan logika penjodohan pola. Logika seperti ini membandingkan pola yang didasarkan atas data empirik dengan pola yang diprediksikan atau dengan beberapa prediksi alternatif. Jika kedua pola ini ada persamaan, hasilnya dapat menguatkan validitas internal studi kasus yang bersangkutan.

Pembuatan Penjelasan (explanation building). Teknik analisis ini bertujuan untuk menganalisi data studi kasus dengan cara membuat suatu eksplanasi tentang kasus yang bersangkutan untuk keberlanjutan suatu studi.

2. Analisis Deret Waktu (time-series analysis)

Teknik analisis deret waktu hampir mirip dengan teknik analisis penjodohan pola. Perbedaannnya terletak pada pola yang dijodohkan. Analisis deret waktu lebih menekankan pada prosedur/kronologis suatu peristiwa (pendekatan eksperimen). Jika hasil penelitian menunjukkan hasil yang tidak sama dengan kronologis yang ditetapkan berdasarkan empiris atau teori, maka hasil tersebut tidak signifikan.

IV. HASIL PENELITIAN DAN PEMBAHASAN Deskripsi Hasil Penelitian

Departemen Agama Kota Surabaya merupakan sebuah lembaga pemerintah dibawah naungan langsung oleh Kementrian Agama. Kantor Departemen Agama Kota Surabaya berada di Jl. Masjid Agung Timur 4 Surabaya. Lembaga ini memiliki visi "Terwujudnya Masyarakat Surabaya Yang Taat Beragama, Rukun, Cerdas, Dan Sejahtera Lahir Batin Dalam Rangka Mewujudkan Indonesia Yang Berdaulat, Mandiri Dan Berkepribadian Berlandaskan Gotong Royong" (Dr.H.Haris Hasanudin, M.Ag.). Tugas pokok Departemen Agama Kota Surabaya diatur dalam pasal 498 yang berbunyi:

Perumusan dan penetapan visi, misi, dan kebijakan teknis di bidang pelayanan dan bimbingan kehidupan Bergama kepada masyarakat di kabupaten/kota;

1. Pelayanan, bimbingan, dan pembinaan di bidang haji dan umroh;

2. Pelayanan, bimbingan dan pembinaan di bidang pendidikan madrasah, pendidikan agama dan keagamaan;

3. Pembinaan kerukunan umat beragama;

4. Pelaksanaan kebijakan teknis di bidang pengelolaan administrasi dan informasi;

5. Pengkoordinasian perencanaan, pengendalian, pengawasan dan evaluasi program; dan Pelaksanaan hubungan dengan pemerintah daerah, instansi terkait, dan lembaga masyarakat dalam rangka pelaksanaan tugas kementerian di kabupaten/kota.

Kebijakan pembayaran Zakat 
Ridho, et al/Jurnal Ekonomi Syariah Teori dan Terapan Vol. 6 No. 6 Juni 2019: 1228-1241; DAMPAK PEMBAYARAN ZAKAT TERHADAP PERILAKU KONSUMSI PEGAWAI NEGERI SIPIL DI DEPARTEMEN AGAMA KOTA SURABAYA

sebagai pengurang penghasilan kena pajak merupakan kebijakan yang dibuat pemerintah dengan tujuan untuk memberikan solusi kepada para pegawai aparatur Negara atau masyarakat umum agar dapat menunaikan kewajiban ganda. Kewajiban ganda adalah gambaran bahwa seorang pekerja yang beragama Islam memiliki dua kewajiban yang harus dilakukan pada pendapatannya yaitu Pajak dan Zakat. Dengan kebijakan tersebut maka seorang pekerja tidak perlu terbebani oleh dua kewajiban tersebut karena kebijakan tersebut sudah sekaligus berjalan seiringan dengan syarat dan ketentuan yang berlaku. Hal ini dicantumkan dalam pasal 22 UndangUndang No.38 tahun 1999 Tentang Pengelolaan Zakat. Disebutkan bahwa:

Zakat yang telah dibayarkan kepada badan amil zakat atau lembaga amil zakat dikurangkan dari laba/pendapatan sisa kena pajak dari Wajib Pajak yang bersangkutan sesuai dengan peraturan perundang-undangan yang berlaku.

Undang - Undang di atas menunjukkan bahwa pemerintah menunjukkan ingin berperan aktif dalam menciptakan pelaksanaan kewajiban keagamaan masyarakatnya dengan menjadikan unsur zakat sebagai salah satu keringanan pajak dalam pemungutan Pajak Penghasilan (PPh) di Indonesia.
Setelah melakukan proses penelitian dengan metode wawancara dengan beberapa narasumber dapat disimpulkan bahwa kebijakan tersebut memiliki dampak yang bermacam-macam terhadap individu masing-masing PNS Departemen Agama Kota Surabaya. Dengan adanya kebijakan tersebut menurut semua narasumber, perilaku konsumsi ketika kebijakan tersebut diterapkan mengalami perubahan. Yang awalnya perilaku konsumsi untuk memenuhi kebutuhan sehari-hari mengalami pemborosan menjadi hemat ketika kebijakan tersebut diterapkan dalam kehidupan berkonsumsi sehari-hari. Semua narasumber juga tidak mengeluh karena gajinya di potong untuk pembayaran zakat. Karena dalam prakteknya, kebijakan tersebut sudah dilakukan sesuai aturan yang berlaku.

Para PNS yang terkena dampak dari kebijakan tersebut hanya menyarankan agar sosialisasi tentang kebijakan tersebut terus dilakukan dan terus dikembangkan agar masyarakat khususnya para PNS tahu jika kebijakan tersebut sangat menguntungkan. Dalam kehidupan berkonsumsi Islam mengajarkan tentang cara berkonsumsi dengan benar sesuai ajaran Al-Qur'an maupun hadits sehingga mampu memberikan petunjuk yang jelas tentang konsumsi agar perilaku konsumsi menjadi terarah (Hidayat:2010). Manusia dalam melakukan pemenuhan kebutuhan 
Ridho, et al/Jurnal Ekonomi Syariah Teori dan Terapan Vol. 6 No. 6 Juni 2019: 1228-1241; DAMPAK PEMBAYARAN ZAKAT TERHADAP PERILAKU KONSUMSI PEGAWAI NEGERI SIPIL DI DEPARTEMEN AGAMA KOTA SURABAYA

hidupnya dan adakalanya perilaku konsumsi juga merupakan kebiasaan dan pemenuhan keinginan seseorang. Perilaku konsumsi yang sesuai dengan ajaran Islam akan memberikan jaminan kehidupan manusia yang adil dan sejahtera dunia dan akhirat.

\section{SIMPULAN}

Kebijakan pembayaran zakat sebagai pengurang penghasilan kena pajak memiliki dampak terhadap perilaku konsumsi pegawai negeri sipil di Departemen Agama Kota Surabaya. Namun dampak tersebut menurut semua narasumber tidak menimbulkan kerugian justru menyebabkan berbagai keuntungan.

Pemungutan zakat yang di bebankan kepada gaji Pegawai Negeri Sipil Departemen Agama Kota Surabaya merupakan salah satu kebijakan pemerintah untuk menambah tingkat kesadaran akan kewajiban menunaikan zakat. Dampak dari terwujudnya kebijakan tersebut juga akan dirasakan kepada meningkatnya Dana Zakat yang akan di distribusikan kepada mustahiq.

Kebijakan tersebut juga memberikan kesadaran para Pegawai Negeri Sipil dalam menerapkan perilaku konsumsi di kehidupan sehari-hari. Yang awalnya perilaku konsumsi belum dilaksanakan secara baik dan benar, dengan adanya kebijakan tersebut maka perilaku konsumsi para PNS berubah menjadi lebih hemat dan tidak ada pemborosan.

Hasil dari penerapan kebijakan tersebut merupakan pencapaian yang cukup bagus untuk tidak saja memberikan kemudahan para PNS Departemen Agama Kota Surabaya dalam membayar zakat namun juga dirasakan oleh mustahiq yang semakin hari semakin bertambah banyak. Dana serapan zakat juga bermanfaat untuk Negara. Misal, untuk infrastruktur, kesehatan dan pendidikan masyarakat umum.

\section{DAFTAR PUSTAKA}

Ad Dimasyqi, Taqiyyuddin. 2005. Kifayah al Akhyar. Beirut: Darul Kutub Al 'Ilmiah. Al Gazali, 1994. Rahasia Puasa dan Zakat. Bandung: Penerbit Karisma.

Al Qurthubi, Abi Abdillah Muhammad ibn Ahmad. 2006. Tafrir Ahkam al Qur'an. Beirut: Al-Resalah Publishers. Az Zuhaili, Wahbah. 1985. Figh Al-Islamiy wa Adillatuhu. Damaskus: Dar al Fikr.

Aziz, Muhammad dan Shalikhah. 2014. Zakat Profesi dalam Perspektif UndangUndang no. 22 Tahun 2011 dan Hukum Islam. Jurnal Ulul Albab Vol. 15, No. 2.

Hafiduddin, Didin 2004. Zakat dalamPerekonomian Modern. Jakarta: Gema Insani.

Hidayat, Ahmad. 2015. Manajemen Zakat dan Perilaku Konsumsi Mustahik. Jurnal Banking and Management Review, Vol. 4, No. 2.

Mariana, Hanik. 2016. Korelasi Zakat dengan 
Ridho, et al/Jurnal Ekonomi Syariah Teori dan Terapan Vol. 6 No. 6 Juni 2019: 1228-1241; DAMPAK PEMBAYARAN ZAKAT TERHADAP PERILAKU KONSUMSI PEGAWAI NEGERI SIPIL DI DEPARTEMEN AGAMA KOTA SURABAYA
Periaku
Konsumen
dan
Pemberdayaan
Ekonomi
Masyarakat di Banyudono,
Ponorogo. Jurnal Muslim Heritage
Vol. 1, No. 1.

P3El, 2010.

Rasyid, Sulaiman. 1994. Fiqh Islam. Bandung:

Sinar Baru Algesindo.

Rosmiati, Nur. 2012. Studi Analisis Pengelolaan Dana Zakat Dalam Mengentaskan Kemiskinan. Makasar: UIN Alaudin.

Sudirman. 2007. Zakat dalam Pusaran Arus Modernitas. Malang: UIN Malang Press.

Al Faizin, Abdul Wahid \& Sri Herianingrum. 2018. Zakat: Concept and Implications to Social and Economic (Economic Tafsir of Al- Tawbah: 103). Journal of Islamic Monetary Economic and Finance Vol. 4, No. 1.

Yasin, Ahmad Hadi. 2012. Panduan Zakat Praktis. Jakarta: Dompet Dhuafa Republika. 